\section{SCIENCE AND THE STATE.1}

I HAVE long held that there is a certain class of work performed by institutions which should undoubtedly be carried on by some department of the State, specially devoted to such work.

The work to which I refer is such as is not suitable, or to be expected from societies or individuals. It is work which is continuous and must expand in the flux of time, which is recognised by the public as useful, which is not and cannot be remunerative, which requires a staff larger than is required by the ordinary demands of a society, and cannot be dropped without serious detriment to the public.

When there is some pressing need Government does administer branches of a department which has to carry out scientific investigation. Thus the medical branch of the Local Government Board has been laboriously and gradually built up. It is far otherwise, however, with that scientific work which has no department specially interested in or needing it, though it is for the public weal; as the State departments only exist for ministering to that weal, it appears that some department should be created or enlarged to take charge of such work. This view, which I have long held has been more than confirmed by the evidence given before a recent committee, which the Treasury practically appointed, to consider the present position of the Meteorological Office, but limiting the recommendation to be made so far as the grant made to it is concerned.

Meteorological science has been greatly retarded in Great Britain by want of funds. Perhaps the latest example occurred in 1902, when there was a proposal to obtain further information about atmospheric currents and conditions by the use of balloon and kite observations, an international scheme of work being contemplated. The small sum of $500 l$. a year would have been necessary to carry out this research, but the Royal Society was obliged, on behalf of the Meteorological Office, to reply that they had no funds, a reply which it would have been difficult to make had the Meteorological Office been part of a Government department. Let us look across the water at our American cousins and see how they regard the science of meteorology, and whether or not it is important enough to attach it to the State. According to evidence given to the committee, the Weather Bureau in America, corresponding to our Meteorological Office and forming part of the Department of Agriculture, was spending 230 ,oool. a year on the same work as that of the Meteorological Committee, whose funds at the maximum were confined to $15,300 l$. In Germany, where very large sums are spent on the oceanic part of meteorology, it is a part of the Navy Department. We, with our splendid navy and mercantile marine, surely ought to see that this part of meteorology is as well cared for as it is in Germany, and that there is no lack of funds. The evidence given before the committee showed that without the help of the hydrographic branch of the Navy the work could not have been carried on with anything like success. I am not intending to enter into a discussion of meteorological science, but it has been pointed out that if forecasts are any good (and we have it on record that from 68 per cent. to 75 per cent. of them are successful) they ought to be made as good as possible. There is no doubt that kite and balloon observations, and the use of wireless telegraphy in mid-ocean, would give a still higher percentage of successful forecasts. But the additions must remain in abeyance owing to the money limit which has been fixed at the same standard for so many years.

Again, we find that a very large item of expenditure by the Meteorological Office is the cost of telegrams. It has to pay the same price for the use of the Post Office telegraphs as any private individual, whereas every Government office has the free use of the wires, and has not to consider whether a telegram runs to 12 or 120 words, or whether it sends 1 or Ioo. The main object of the Meteorological Office is to assist the public, and this is the same as that of Government departments, yet the one is hampered by the cost of publishing information (which to be of the

1 Abridged from the inaugural address delivered at the Society of Arts on November 16 by Sir William Abney, K.C.B., F.R.S., vice-president and chairman of the council of the Society. greatest use must be transmitted at once), whilst the other is not. The view of the committee which sat was strongly that this disability ought to be removed, so that wide publicity to weather reports, especially in harvest time, should be given. Finally, the committee almost unanimously reported in favour of the office being attached to some Government department, and proposed that this should be the Board of Agriculture, a department which at present is not overweighted.

1 must remind you that our great Indian dependency has been more alive to the question of meteorology than we have at home; but I trust that, backivard as we are, we may, before long, attain that excellence of administration which the Indian Meteorological Department has exhibited under its present and past able administrators.

What the Government intends to do with the committee's report I do not know. Judging from previous history, there seems to be a dread at the Treasury of any of the present departments having more to do with science than is absolutely forced upon them. Perhaps this is natural. The lay official mind has, with some few exceptions, never fully grasped the importance of orderly and continued scientific investigation in order to increase national prosperity. It recognises this in a way, for the need is continually brought into prominence by the Press, but to it the easiest plan is to leave all such investigation to societies. In Great Britain it has never been realised that to foster such work is a duty of the nation. We have ignored the very patent fact that in free America and in other couritries the necessity of annexing to the State all utilitarian research (when such research is carried out with the definite object of public usefulness) is fully recognised. I am not proposing for an instant that the work which is carried out by individuals or societies should be curtailed, but there are questions which are too large, too expansive, and bearing too much on the public weal which should be dealt with in Great Britain as they are in (say) America.

I have only so far referred to the Meteorological Committee, but, at all events, there is another institution, the National Physical Laboratory, which should come into the same category of quasi-public departments.

The Government has given the National Physical Laboratory buildings, and a sum of $19,000 \mathrm{l}$. to make the additions to them, which were absolutely necessary to commence with. It granted $4000 l$. a year for four years, and afforded assistance to it through the Office of Works. The term of years for which the grant was made runs out in March next, and its financial position has to be reviewed by the State through the Treasury. Its existence and development has become a necessity through the excellent work that it has already done. But there is work of first-class importance to the public which the laboratory has been forced to refuse owing to lack of funds. Standardising is not a luxury in the present day, and England has suffered much in its trade owing to the want of it.

The table on p. $9 \mathrm{r}$ will show the amounts granted by the different States in regard to these laboratories.

Here we have a direct comparison of grants and turn-out of work. Great Britain, I think I may say, has no reason to be ashamed of the work, though it has of the grants. In connection with the results given in the table, I- may point out that France and the United States started their institutions after the inauguration of our own laboratory.

The idea of making any such institution a State institution, it may be supposed, was never entertained by the Government, such a notion being foreign to existing precedent. The precedent-bad precedent too-had to govern the situation. We have only to look across the Atlantic to see how our Anglo-Saxon cousins treat such matters. There, institutions such as I have here described are part and parcel of a State department, and have a handsome annual grant allotted to them. The Government of the United States recognised the public need, and so did Congress, with the result that the public need is catered for by a public department, as it should be.

In regard to the National Physical Laboratory, it is no secret that at the present moment it is hampered by want of funds for equipment and staff. Its refusal of work has only proceeded from this cause. The report which it issued showed that its expenditure had been larger than its income NO. I830, VOL. 71$]$ 
of $9000 l$, an income which is derived from a variety of sources:-Treasury grant, 400ol.; Gassiot Fund, 40ol. (about); from Meteorological Committee, 40ol.; fees, \&c., $4200 l$. (about). In addition to this there has been I20ol. in donations.

Whether the laboratory can become self-supporting is a matter of doubt to my mind. Even if it should be so, that is no reason for taking it away from State control, which always gives an impress to decisions, and it is a pledge that gain is not its only object. Certainly it would never arrive at the proportions that the huge, more than self-supporting department, the Post Office, has arrived at. The example of Germany, where the State takes the fees, and supports the institution, is worth following.

\section{THE BEN BULBEN DISTRICT.}

THE region lying north of Sligo, which was visited by a large party of naturalists last July on the occasion of the fourth triennial conference of the Naturalists' Field Clubs of Ireland, is one of much beauty and interest. In its general aspect it recalls the best features of the Yorkshire Carboniferous Limestone area. Its setting, with the great limestone plain of Ireland stretching away on one hand, and the Atlantic Ocean on another, adds a dignity and impressiveness to this group of cliff-rimmed, fiat-topped hills which might not be bestowed by their height alone, though they are of no mean elevation (Truskmore, the highest point, rises to $2 \mathrm{II}_{3}$ feet). The Ben Bulben range,

\begin{tabular}{|c|c|c|c|c|c|c|}
\hline \multirow{2}{*}{ Country } & \multirow{2}{*}{ Name } & Cost & \multirow{2}{*}{$\underset{\text { Grant }}{\text { Annual }}$} & \multirow{2}{*}{$\begin{array}{l}\text { Receipts } \\
\text { from } \\
\text { annual } \\
\text { work }\end{array}$} & \multirow{2}{*}{$\begin{array}{c}\text { No. of } \\
\text { tests made }\end{array}$} & \multirow{2}{*}{ Staff } \\
\hline & & Building Equipment & & & & \\
\hline Germany $\ldots \quad \ldots$ & $\begin{array}{lll}\text { Reichsanstalt } & \ldots & \ldots \\
\text { Aichungs-kommission } & \ldots \\
\text { Versuchsanstalt } \quad \ldots & \ldots\end{array}$ & $\begin{array}{r}£ 200,000 \\
48,000 \\
137,000\end{array}$ & $\begin{array}{r}£ 16,000 \\
8,500 \\
15,000\end{array}$ & $\frac{£ 3,000^{2}}{-}$ & $\frac{22,469}{5, \infty 00}$ & $\frac{112}{140}$ \\
\hline $\begin{array}{lll}\text { France } & \ldots & \ldots\end{array}$ & Laboratoire de l'état & $\begin{array}{l}\qquad 3^{85}, 000 \\
£ 27, \infty 00 \quad £ 20,000 \\
\text { and some } \\
\text { buildings. }\end{array}$ & $\begin{array}{r}£ 39,500 \\
5,500\end{array}$ & $£ \mathrm{II}, 000$ & 27,469 & $\begin{array}{r}252 \\
12\end{array}$ \\
\hline $\begin{array}{l}\text { U.S.A. } \ldots . . . \\
\text { Great Britain.. }\end{array}$ & $\begin{array}{l}\text { Bureau of Standards } \\
\text { National Physical Laboratory }\end{array}$ & $\begin{array}{lc}£ 70,000 & 45,000 \\
£ 19,000 & \\
\text { including } & 1 \\
\text { some } & \\
\text { buildings. } & \end{array}$ & $\begin{array}{r}19,000 \\
4,000\end{array}$ & $\begin{aligned} 114^{* 3} \\
4,042^{4}\end{aligned}$ & $\begin{array}{r}1,666^{3} \\
30,807^{4}\end{array}$ & $\begin{array}{l}22 \\
50\end{array}$ \\
\hline
\end{tabular}

1 The annual grant was made before the work was started, and any balance left after paying salaries I believe was available for apparatus.

I might refer to researches in solar physics also, which are carried out in the iron shanties at South Kensington, under the control of the Board of Education. The sum of 70ol. is allotted as a grant in aid for the work that is carried out there, and some of the staff are borne on the estimates but if, as is to be believed, some of the tremendous problems of the causes of famine and plenty are dependent on the solar phenomena, then this work should be enlarged and encouraged. The expenditure of ten times the sum in one year may enable millions of pounds and lives to be saved which may be lost from the scant supply of needful means. It is true that the Solar Physics Observatory is under the Board of Education, but if its history were written, I doubt not that it would be found that from its very first inception (due to the repeated recommendation of a host of scientific men who foresaw something of what might be expected from it) the State wanted none of it. It may be said that if the Meteorological Office and the National Physical Laboratory were attached to a Government department, they might be starved in the same way. I do not believe it possible that such would be the case, for these two are of ostensible use to the ordinary public, and appeal to that most sagacious and popular person the man in the street, in a way that solar physics does not. The last deals with problems which are for future use, but it is intimately, most intimately, connected with meteorology. If the Meteorological Office becomes attached, as it eventually must be, to a Government department, the Solar Physics Observatory and staff should be attached to the same department.

If the Government will recognise the two institutions as doing essentially public service, and ask for the necessary funds, I believe Parliament would vote the supplies in the same ungrudging manner that Congress has done, as they would look upon them as a paying investment. Parliament realises most frequently before Government does the importance of any public work. The most happy solution of the problem would be (I) to have some department of State to which these and other kindred scientific institutions should be attached; (2) to have a scientific advisory board; (3) to distinguish clearly between grants for research, equipment, and material, and those for staff.

NO. 1830 , VOL. 7 I] which derives its name from that of one of its spurs which projects boldly towards the Atlantic, represents the wreck of the Upper Limestone of this district. The fertile undulating low grounds all around are occupied by a lower and more argillaceous series, through which one of the old Caledonian folds of Ireland projects as a knobby ridge, its rugged outlines forming a charming contrast with the green and grey tabular forms of the limestone. The Upper Limestone, 700 feet or 800 feet thick, massive and strongly jointed vertically, rests on the lower series as a cliff-bound plateau, intersected by several grand glens, which are cut through the limestone deep into the less resisting rocks underneath. The mural precipices are the result of the characteristic weathering of the massive limestones. Below them, where not obscured by talus, the Middle Limestones and shales fall away in steep concave slopes into the plain. The exquisite valleys of Glencar and Glenade cut right through the plateau, the first in an east and west direction, the other north and south. Each is from one to two miles wide from cliff-top to cliff-top, and about a thousand feet deep (Fig. I). The fioors of these valleys are undulating, and the scenery is much enhanced by the fact that each embosoms a lake at the point where the cliff scenery reaches its best.

On some parts of the plateau-edge denudation has been more severe, as in the beautiful wedge of Ben Whiskin (1666 feet), the western side of which displays a characteristic precipitous front, while the eastern side has been worn down to a uniform steep slope which drops into Gleniff.

The uniformity of the post-Carboniferous uplift is shown by the almost absolute horizontality of the beds of limestone throughout the region. The surface of the plateau, while retaining in a general way this horizontality, is seen on a nearer approach to be undulating, a feature chiefly due to the fact that patches of the Yoredale sandstone still remain here and there isolated on the surface of the limestone. The whole plateau, limestone as well as sandstone, has in general a thick covering of peat.

To the botanist the Ben Bulben range is well known as the only British habitat of Arenaria ciliata, a species with a high northern and alpine distribution, which is locally 